\title{
The Danube: Dams over troubled waters
}

\section{London}

HUNGARY is threatening to cut off river, rail and road traffic to Czechoslovakia in retaliation for the imminent resumption of construction of the controversial Gabcikovo-Nagymaros hydroelectric project on the Danube River. The emotionally charged project provoked heated new demonstrations last year in Prague and Vienna as well as a dozen West European cities.

Hungary has abandoned its part of the hydroelectric construction programme at Nagymaros, in the scenic Danube Bend north of Budapest, for environmental reasons. But Slovakia, the smaller of the two states comprising Czechoslovakia, has decided that its own construction work already carried out on the Gabcikovo dam south of Bratislava has dealt such irreparable damage to the environment that it should now be completed as the lesser of two evils.

Austria is seeking compensation for its original $\$ 640$ million investment in the 15-year-old joint programme which should have been repaid in hydro-power by now. Hungary and Czechoslovakia have each invested about $\$ 500$ million, but most of the construction has taken place in Czechoslovakia where officials insist that the unfinished project cannot just be abandoned.

Environmentalists in all three countries have opposed the project from its inception, arguing that the dams would change the flow of ground water, pollute drinking water, damage agriculture and forestry and dry up the river's vast inland delta which constitutes a unique wetland rich in wildlife.

The two dams would need to operate in conjunction to reap the maximum potential power yield of the river. The Gabcikovo project, which is now expected to be completed "provisionally" this year, should produce in about three years 180 MW instead of the originally planned 780 MW of electric power.

The original plans of the joint project would have involved a re-drawing of the border between the two countries, which cannot now be completed without Hungary's permission. The border is the river itself which was to have had a weir built across it to divert part of the flow. Hungary has just demonstrated its determination to wind up the project by inviting tenders for demolition of the unfinished barrage in the Danube Bend and restoring that section of the river to its former state.

Not so Czechoslovakia. Under a compromise plan known as the ' $\mathrm{C}$ ' variant, a $17 \mathrm{~km}$ canal already completed in Slovakia will now be extended by another $9 \mathrm{~km}$ upstream where both sides of the river are on Czechoslovak territory and water management can therefore be treated as an internal matter.

If Hungary retaliates by blocking the trade arteries of the landlocked region, there could be far-reaching effects. Public opinion in Hungary would certainly support such a drastic measure. So would important segments of population in

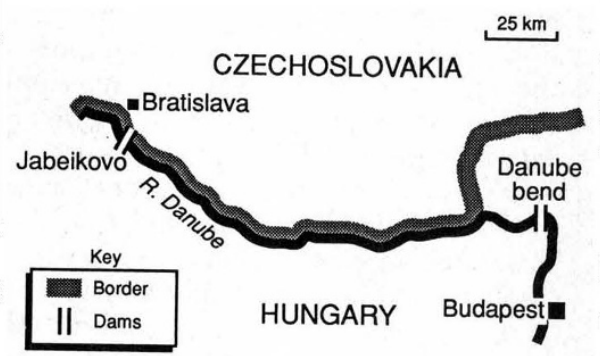

Danube dams spur controversy.

Czechoslovakia - particularly the large Hungarian ethnic minority in Slovakia. The influential global environment protection movement would also be sympathetic. But a disruption of goods transport would damage business and commerce in Central Europe just as the region is trying to to pick its way out of the economic ruins of communism by changing to a market economy.

The Swiss-based World Wide Fund for Nature, which has taken a special interest in the controversy, says the construction of the dam in Slovakia has already required the razing of $100 \mathrm{sq} . \mathrm{km}$ of forest and farmland and the devastation of a $40 \mathrm{sq} . \mathrm{km}$ area which has been covered with concrete.

The mayors of 80 towns adjacent to the project area are supporting a petition seeking a moratorium on new construction. They are campaigning for the establishment of an international scientific commission to look into the broad economic as well as environmental consequences of the project.

But not all news of the Danube is gloomy. All the countries of the river basin are involved in a programme launched late last year under the auspices of the United Nations and the European Community to clean up the common environment. The $\$ 35$ million first phase of the programme will bring together many scientific research and training institutions to improve water pollution monitoring and data management among other things. Thomas Land
Biotech lobby pressures EC

\section{London}

EUROPE's biotechnology companies are stepping up their efforts to combat what they see as the European Communities' (EC) muddled policies towards the industry. The Senior Advisory Group on Biotechnology (SAGB), set up in 1989 by nine of Europe's largest chemicals companies (including ICI, Hoffmann-La Roche and Ciba Geigy), is expanding to include 28 of Europe's leading biotechnology concerns. The move recognizes the fact that the policies of the $\mathrm{EC}$, not those of individual governments, now have the biggest influence over the European biotechnology industry.

The advisory group has consistently argued that existing product-safety legislation is sufficient to regulate the industry, and that additional EC controls over genetic engineering will make it difficult for Europe's biotechnology companies to compete with US and Japanese competitors (see Nature 343, $501 ; 1990)$. A year ago, SAGB called projects being supported by the EC "too limited in both scope and scale to have a lasting impact and give a clear European profile".

Brian Ager, from SAGB's office in Brussels, says that the European Commission's stated policy on biotechnology, released last year, recognized this concern, but he believes that continued pressure is needed to ensure that this policy document is acted upon. "We still haven't got it right in Europe," he says.

The expansion of the advisory group follows the establishment of another industry lobby group, the European Secretariat of National BioIndustry Associations, which also plans to open a Brussels office. Its first concern is likely to be a directive on the transport of genetically engineered organisms, now being drafted by European Commission transport officials, which biotechnology companies fear will be far more restrictive than anything planned in the rest of the developed world. The advisory group hopes the EC will treat genetically engineered products according to their inherent characteristics, not method of manufacture.

A major priority for both lobby groups is the adoption of a planned EC directive on the patenting of biotechnological inventions, first launched in 1988 , but which has become stalled in the European Parliament amid controversy surrounding a proposal to allow the patenting of transgenic animals.

Peter Aldhous 